\title{
Indian Textile Industry: Opportunities, Challenges and Suggestions
}

\author{
Satish Kumar R* \\ Professor and Chair for Marketing Area, India \\ *Corresponding author: Satish Kumar R, Professor and Chair for Marketing Area, IFIM Business School, Bangalore, India \\ submission: 侐 March 06, 2018; Published:
}

\begin{abstract}
The Indian textile industry is highly fragmented and labor-intensive. The textile industry is being dominated by unorganized sector and Small and medium industries. The foreign investors are not investing in the textile sector which is also one of the areas of concern. The government policies and tax structure are not favoring this industry textile industry is highly competitive and the present situation demands the companies to benchmark their products with the best in the world and try to upgrade the quality and production processes. The paper tries to provide insights into the Indian textile industry. The article attempts to explain the opportunities, challenges and suggestions.
\end{abstract}

Keywords: Benchmark; Textile and garment industry; Labor-intensive; Buyer-driven value chains; Producer driven value chains

\section{Introduction}

India is the world's second largest producer of textiles and garments after China. It is the world's third largest producer of cotton after China and the USA and the second largest cotton consumer after China. Indian textile industry currently estimated to be US $\$ 108$ billion and expected to reach US $\$ 209$ billion in the year 2021.The industry is the second largest employment generator after agriculture by employing 45 million people directly and 60 million people indirectly [1].

The Indian textile industry presently contributes around 14 percent to industrial production, and 4 percent to GDP, 17 percent to the country's exports, and 21 percent employment. India has abundance of natural resources like cotton, jute and silk. Indian products are preferred for their fine designing, embellishment and craft. From the ages the Indian fabric designers and weavers are recognized as one of the best in the world. At present industry is growing at 9-10 percent with Indian economy. Indian textile industry currently possesses a share of $4.7 \%$ in world market of textiles and clothing [2].

Export of clothing from India is increasing world over due to the versatility of different products. The major retailers include JC Penney, Nautica, Dockers, Bed, Bath and Beyond, Target, Kohl's Liz, Calvin Klein, Sprit, Marks \& Spencer, GAP, United Colors of Benetton, Mango, Zara and Dillard's etc. European Union and USA the largest marketsfor textile and apparel with a share of $36 \%$ and $14 \%$ respectively. Among the nations, China is the largest supplier of textile andapparel in the world with a major share of $40 \%$. It is distantly followedby countries suchasIndia, Italy, and Germany etc. each with an approximate share of $5 \%$ in the global textile and apparel exports [1].

The global luxury industry has seen steady growth over the past 16 years [3] and it is commonly believed to be one of the most appealing and profitable industries in the world. In addition to its economic value, luxury fashions brands help develop the best fashion products for the market. They are leaders in the fashion world and drive a lot of mass-market imitators. Moore and Birtwistle (2005) focused on Gucci to study the nature of "parenting advantage" in luxury fashion. They reviewed Gucci's annual reports and other secondary information sources and identified the "ten-year renaissance" in Gucci. They argued that there is an intra business group synergy in Gucci and this synergy is crucial for saving Gucci from the financial crisis that it faced at that time. They also established a multidimensional luxury fashion branding model which identifies various critical components and their interactions for luxury fashion brands. They believed that their proposed model can help luxury fashion brands to better shape the branding strategies and develop a competitive edge. Fionda [4] adopted a qualitative multiple-case study approach to investigate the most important dimensions for the success of luxury fashion brands. They studied 12 international luxury fashion retailers and collected data via both semi-structured interviews with managers of the target companies and reviews of some secondary sources 
such as internal documents and media reports. They successfully obtained nine interrelated attributes which are critical to the success of luxury fashion branding. They concluded their study with a comment on the fact that luxury fashion brand management is complex in general, and the luxury fashion brands should adopt a coherent approach in order to succeed. Moore [5] investigated the use of flagship stores as a market entrance strategy in luxury fashion retailing. They studied 12 luxury fashion retailers and obtained the primary data via semi-structured interviews. From the collected data and observed industrial strategies, they proposed several characteristics of the flagship stores of the luxury fashion retailers. They revealed that luxury fashion retailing flagship stores can be treated as a strategy which can provide substantial support for the development of luxury fashion retailing in a foreign market. In other words, these flagship stores play a crucial role in helping the luxury fashion retailers to enter another market and go international. They also interestingly showed the interdependence of flagship stores and the wholesaling method for luxury fashion brands. Stankeviciute [6] explored brand extension strategy in luxury fashion. They examined several famous international luxury fashion brands, namely Giorgio Armani, Calvin Klein, and Jimmy Choo. They found that luxury fashion brands can collaborate with no luxury brands to develop an extended co-brand. This extension can achieve a positive impact on them if the co-brand possesses the luxury fashion's features, and the no luxury brands have good reputation. They further revealed that a downward brand extension can enhance the parent luxury brands if the extension keeps the parent brands' luxury fashion elements and other critical core brand elements. They also studied the brand dilution effect and argued that the luxury fashion brands have to continuously improve themselves so as to yield a successful portfolio of their brands under the brand extension strategies. Recently, Nobbs et al. [7] explored the essential elements of the luxury fashion flagship store's format. They revealed that the luxury fashion flagship store's scale and size in practice are more than sufficient compared to its functional requirements. They argued that the luxury fashion flagship stores treasure exclusivity and uniqueness most and help attract customers' visit. They explored the characteristics of the luxury flagship store format and demonstrated how the flagship store helps generate and communicate differentiation.

\section{Indian textile industry opportunities}

The fundamental strength of Indian textile industry is its strong production base with wide range of fibers/yarns. These are natural fibers such as cotton, jute, silk and wool and synthetic/man-made fibers like polyester, viscose, nylon and acrylic. In producer-driven value chains, large, usually transnational, manufacturers play the central roles in coordinating production networks. Textile industry is capital- and technology-intensive comparable with automobiles, aircraft, computers, semiconductors and heavy machinery industry. Buyer-driven value chains are those in which large retailers, marketers and branded manufacturers play the pivotal roles in setting up decentralized production networks in a variety of exporting countries, typically located in developing countries. This pattern of trade-led industrialization has become common in laborintensive, consumer-goods industries such as garments, footwear, toys, handicrafts and consumer electronics. Large manufacturers control the producer-driven value chains at the point of production, while marketers and merchandisers exercise the main leverage in buyer-driven value chains at the design and retail stages. Apparel is an ideal industry for examining the dynamics of buyer-driven value chains. The relative ease of setting up clothing companies, coupled with the prevalence of developed-country protectionism in this sector, has led to an unparalleled diversity of garment exporters in the third world. Apparel is an ideal industry for examining the dynamics of buyer-driven value chains.

The global apparel market size is expected to reach US $\$ 2.6$ trillion in 2025 growing by a projected rate of $4 \%$. The major growth drivers of the global apparel market will be the developing economies, mainly China and India, both growing in double digits. China will become the biggest apparel market adding more than US $\$ 378$ bn. in market size by 2025 , while India will be the second most attractive apparel market adding around US \$121 bn. by 2025 [1].

A large and growing domestic demand coupled with increasing spending power of people in these two countries will result in the combined addition of around US $\$ 500 \mathrm{bn}$. in the global apparel market size by 2025. The combined apparelmarket size ofChina andIndia i.e. US $\$ 795 \mathrm{bn}$. is expected to exceed combinedmarketsize of EU and USA i.e. US $\$ 775$ bn, by 2025 . India is one of the fastest growing economies with the GDP growth of 7.2 percent in the last quarter of 2017-18. This growth also boosts the purchasing power and propel the demand for the textile products [2].

India has a share of approximately $5 \%$ of the global textile and apparel trade. The break-up of our current exports are as follows: (Table 1 \& 2).

Table 1: Export share of different goods [8].

\begin{tabular}{|c|c|c|}
\hline S1. No. & Items & Share $\%$ \\
\hline 1 & Cotton Fibre & $9 \%$ \\
\hline 2 & Cotton Yarn, Fabrics and Made ups & $23 \%$ \\
\hline 3 & Man-made Textiles & $14 \%$ \\
\hline 4 & Garments & $39 \%$ \\
\hline 5 & Handlooms and Handicrafts & $11 \%$ \\
\hline 6 & Others & $4 \%$ \\
\hline
\end{tabular}

Table 2: Projections for India in world exports [8].

\begin{tabular}{|c|c|c|}
\hline Year & World Textile Exports \$ Billion & India's Exports \$ Billion \\
\hline 2016 & 860.6 & 54.4 \\
\hline 2017 & 903.6 & 62.6 \\
\hline 2018 & 948.8 & 72.1 \\
\hline 2019 & 996.2 & 83.0 \\
\hline 2020 & 1046.0 & 95.5 \\
\hline 2021 & 1098.3 & 109.9 \\
\hline 2022 & 1153.3 & 126.5 \\
\hline 2023 & 1210.9 & 145.6 \\
\hline
\end{tabular}


The growth of Indian E-Commerce companies provides opportunities for the Indian textile industry in the domestic as well as international market. Amazon, Flipkart, Jabong and Myntra are the major players IN Indian E-Commerce Industry. India's textiles sector is one of the oldest industries in Indian economy dating back several centuries. Even today, textiles sector is one of the largest contributors to India's exports with approximately 13 per cent of total exports. The textile industry is also labor intensive and is one of the largest employers. The textile industry has two broad segments. First, the unorganized sector consists of handloom, handicrafts and sericulture, which are operated on a small scale and through traditional tools and methods. The second is the organized sector consisting of spinning, apparel and garments segment which apply modern machinery and techniques such as economies of scale. The textile industry employs about 45 million people directly and 20 million people indirectly. India's overall textile exports during FY 2015-16 stood at US\$ 40 billion. The Indian textiles industry is extremely varied, with the hand-spun and hand-woven textiles sectors at one end of the spectrum, while the capital intensive sophisticated mills sector at the other end of the spectrum. The decentralized power looms/ hosiery and knitting sector form the largest component of the textiles sector. The close linkage of the textile industry to agriculture (for raw materials such as cotton) and the ancient culture and traditions of the country in terms of textiles make the Indian textiles sector unique in comparison to the industries of other countries. The Indian textile industry has the capacity to produce a wide variety of products suitable to different market segments, both within India and across the world [8].

\section{Indian textile industry}

The Indian textiles industry, currently estimated at around US $\$ 120$ billion, is expected to reach US $\$ 230$ billion by 2020 . The Indian Textile Industry contributes approximately 2 per cent to India's Gross Domestic Product (GDP), 10 per cent of manufacturing production and 14 per cent to overall Index of Industrial Production (IIP). Indian khadi products sales increased by 33 per cent yearon-year to Rs 2,005 crore (US \$311.31 million) in 2016-17 and is expected to exceed Rs 5,000 crore (US $\$ 776.33$ million) sales target for 2018-19, as per the Khadi and Village Industries Commission (KVIC). The production of cotton in India is estimated to increase by 9.3 per cent year-on-year to reach 37.7 million bales in FY 2017 18. The total area under cultivation of cotton in India is expected to increase by 7 per cent to 11.3 million hectares in 2017-18, because of expectations of better returns from rising prices and improved crop yields during the year 2016-17. Indian exports of locally made retail and lifestyle products grew at a compound annual growth rate (CAGR) of 10 per cent from 2013 to 2016, mainly led by bedding bath and home decor products and textiles [8].

\section{Investment in textile sector}

The textiles sector has witnessed a growth in Foreign Direct Investment during the last five years. The industry (including dyed and printed) attracted Foreign Direct Investment (FDI) worth US $\$ 2.82$ billion during April 2000 to December 2017 [8].
Some of the major investments in the Indian textiles industry are as follows:

a) The Cabinet Committee on Economic Affairs (CCEA), Government of India has approved a new skill development scheme named 'Scheme for Capacity Building in Textile Sector (SCBTS)' with an outlay of Rs 1,300 crore (US \$202.9 million) from 2017-18 to 2019-20.

b) Future Group is planning to open 80 new stores under its affordable fashion format, Fashion at Big Bazaar (FBB), and is targeting sales of 230 million units of garments by March 2018, which is expected to grow to 800 million units by 2021 .

c) Raymond has partnered with Khadi and Village Industries Commission (KVIC) to sell Khadi-marked readymade garments and fabric in KVIC and Raymond outlets across India.

Max Fashion, a part of Dubai based Landmark Group, plans to expand its sales network to 400 stores in 120 cities by investing Rs 400 crore (US $\$ 60$ million) in the next 4 years [8].

\section{Government initiatives}

The Indian government has come up with a number of export promotion policies for the textiles sector. It has also allowed 100 per cent FDI in the Indian textiles sector under the automatic route.

Initiative will be taken into consideration by Government of India.

a) The Union Ministry of Textiles Government of India along with Energy Efficiency Services Ltd (EESL), has introduced a technology up gradation scheme called SAATHI (Sustainable and Accelerated Adoption of Efficient Textile Technologies to Help Small Industries) for reviving the power loom sector of India.

b) The Government has taken initiative to connect with 5 crore (50 million) village women to charkha (spinning wheel) in next 5 years with a view to provide them employment and promote khadi and also, they inaugurated 60 khadi outlets which were renovated and re-launched during the completion of KVIC s 60th anniversary and a khadi outlet.

c) The Textiles Ministry will organize 'Hastkala Sahyog Shivirs' in 421 handloom-handicrafts clusters across the country which will benefit over 1.2 lakh weavers and artisans.

d) The Gujarat government's decision to extend its textile policy by a year is set. It is estimated to attract Rs 5,000 crore (US $\$ 50$ billion) of more investment in sectors across the value chain. The government estimates addition till now of a million units of spindle capacity in the spinning sector and setting up of over 1,000 units in technical textiles.

e) The Textile Ministry of India earmarked Rs 690 crore (US \$106.58 million) for setting up 21 ready- made garment manufacturing units in seven states for development and modernization of Indian Textile Sector. 
Some of initiatives taken by the government to further promote the industry are as under:

a) The Directorate General of Foreign Trade (DGFT) has revised rates for incentives under the Merchandise Exports from India Scheme (MEIS) for two subsectors of Textiles Industry - Readymade garments and Made ups - from 2 per cent to 4 per cent.

The Government of India plans to introduce a mega package for the power loom sector, which will include social welfare schemes, insurance cover, cluster development, and up gradation of obsolete looms, along with tax benefits and marketing support, which is expected to improve the status of power loom weavers in the country [8].

\section{Indian textile industry challenges}

The Indian textile industry is highly fragmented and is being dominated by the unorganized sector and small and medium industries. The changing government policies at the state and central government levels are posing major challenges to the textile industry. The tax structure GST (Goods and Service Tax) make the garments expensive. Another important thereat is raising interest rates and labor wages and workers' salaries. There is higher level of attrition in the garment industry. Although central government is wooing the foreign investors the investment is coming in the textile industry. In India places such as Bangalore, Mumbai, New Delhi and Tirupur are the hubs of textile garment industries. These manufacturers have ability to produce the entire range of woven wear and knitwear at low cost with reasonably good quality within the short notices. The Indian textile industry has its own limitations such as accesses to latest technology and failures to meet global standards in the highly competitive export market. There is fierce competition from China, Bangladesh and Sri Lanka in the low price garment market. In the global market tariff and non-tariff barriers coupled with quota is posing major challenge to the Indian textile Industry. The environmental and social issues like child labor and personal safety norms are also some of the challenges for the textile industry in India [8-12].

\section{Conclusion}

The Indian textile industry requires support from both the Central and State governments to become competitive in the Global market. The Skill India and Make-in India programs of Central government headed by Prime Minister Sri Narendra Modi is helping the industry in getting required skilled manpower and good market for textile products. It is high time for the textile industry to upgrade their technology and implement ERP to streamline supply chain and enhance customer relations management activities. These measures are enabling the industry in becoming competitive in the global market. The future for the Indian textile industry looks promising, buoyed by both strong domestic consumption as well as export demand. With consumerism and disposable income on the rise, the retail sector has experienced a rapid growth in the last decade with the entry of several international players like Marks \& Spencer, Guess and Next into the Indian market.

The future for the Indian textile industry looks promising, buoyed by both strong domestic consumption as well as export demand. With consumerism and disposable income on the rise, the retail sector has experienced a rapid growth in the past decade with the entry of several international players like Marks \& Spencer, Guess and Next into the Indian market. The organised apparel segment is expected to grow at a Compound Annual Growth Rate (CAGR) of more than 13 per cent over a 10-year period

The Union Ministry of Textiles, which has set a target of doubling textile exports in 10 years, plans to enter into bilateral agreements with Africa and Australia along with working on a new textile policy to promote value addition, apart from finalising guidelines for the revised Textile up gradation Fund Scheme (TUFS). The Indian cotton textile industry is expected to showcase a stable growth in FY2017-18, supported by stable input prices, healthy capacity utilisation and steady domestic demand.

High economic growth has resulted in higher disposable income. This has led to rise in demand for products creating a huge domestic market. The domestic market for apparel and lifestyle products, currently estimated at US\$ 85 billion, is expected to reach US $\$ 160$ billion by 2025 . The Indian cotton textile industry is expected to showcase a stable growth in FY2017-18, supported by stable input prices, healthy capacity utilization and steady domestic demand.

\section{References}

1. Gulrajani ML, Gupta D (1992) Natural dye and their application to textiles. Department of Textile Technology, Indian Institute of Technology, New Delhi, India.

2. (2002) SERI: Colour from nature silk dyeing using natural dyes, SERI 2000, Oxford and IBH publishing Co. Pvt. Ltd., New Delhi, India.

3. Samanta AK, Konar Adwaita (2012) Technical handbook on natural dye and colouration. Department of Jute and Fibre Tech, IJT, Calcutta University, Kolkata, India, pp. 45-72.

4. Bhattacharya N (1999) Natural dye-Its authenticity and identification. Convention Proceedings, 1st Convention on Natural Dyes, Department of Textile Technology, IIT Delhi, India, p. 134.

5. Vankar PS, V Tiwari, Ghorpade B (2001) Supercritical fluid extraction of natural dye from eucalyptus bark. Convention Proceedings, 2nd Convention on Natural Dyes, Department of Textiles Technology, IIT Delhi, India, p. 53.

6. Samanta AK, Agarwal P (2009) Application of natural dyes on textiles. Indian Journal of Fibre \& Textile Research 34: 384-399.

7. Tiwari V, Vankar PS (2001) Unconventional natural dyeing using microwave and sonicator with alkanet root bark. Asian Textile J 10(56): 54 .

8. Samanta AK, Singhee D, Sethia M (2001) Application of single and mixture of selected natural dyes on cotton. Convention Proceedings, 2nd Convention on Natural Dyes, Department of Textiles Technology, IIT Delhi, India, p. 20. 
9. Samanta AK, Agarwal P, Konar A, D Siddhartha (2008) Characterization and application of purified selective natural dyes on jute. International Dyer 193(3): 25-33.

10. Samanta AK, Agarwal P (2008) Application of mixture of red sandal wood and other natural dyes for dyeing of jute fabric-studies on dye compatibility. International Dyer 193(3): 37-41.
11. Samanta AK, Agarwal P, Datta Siddhartha (2008) Dyeing of jute with binary mixtures of jackfruit wood and other natural dyes: study on colour performance and dye compatibility. Indian J Fibre \& Text Res 33: 171-180.

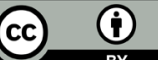

Creative Commons Attribution 4.0 International License

For possible submissions Click Here

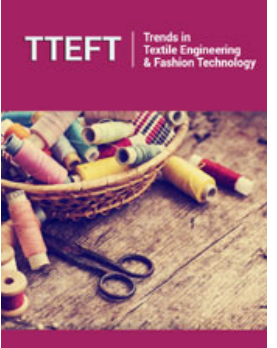

Trends in Textile Engineering \& Fashion Technology

\section{Benefits of Publishing with us}

- High-level peer review and editorial services

- Freely accessible online immediately upon publication

- Authors retain the copyright to their work

- Licensing it under a Creative Commons license

- Visibility through different online platforms 